ХОРОВІ ТВОРИ ІГОРЯ ШАМО ТА ЇХНІЙ МЕТОДОЛОГІЧНИЙ ПОТЕНЦІАЛ

\title{
CHOIR'S WORKS BY IGOR SHAMO AND THEIR METHODOLOGICAL POTENTIAL
}

У статті висвітлено особливості хорових творів Ігоря Шамо. Наголошено увагу на місці цих творів у хоровій літературі України. Визначено основні риси, притаманні хоровій творчості композитора. Композиторський метод Шамо, пов'язаний із відтворенням фолььклорних образів, які втілюються в авторському матеріалі. Наявні яскравий мелодизм, інтонаційна близькість до народних пісень, велика увага до програмного начала. Музична мова Шамо є досить мелодійною та виразною, водночас вона розвивається згідно із сучасними техніками та композиційними прийомами. Зазначено прагнення композитора представити інтонаційні шари, які дотичні до архайчних фрорм фольклору. В хорових композичіях використовуються мелодії з превалюванням остинантного принципу, інтонаційних зворотів невеликого амбітусу, з обіграванням інтервалів секунди та кварти. Наявність стрибків досить часто компенсується заповненням їх низхідним чи висхідним поступальним рухом. Композитором використовуються такі елементи, як скандування, шепіт, вигуки, що уподібнює їх до народного музикування, а також відповідає провідним тенденціям композиторської творчості. Використання ладів народної музики підкреслює зв'язок із фольклорними витоками. Нерідко наявні акордові побудови, які є результатом лінеарного мислення. Зазначено такі характерні прийоми хорового письма, як зіставлення хорових груп, комбінування різних виконавських складів, градація динамічного та експресивного рівнів. Використання різних хорових груп дає можливість видобути найменші нюанси, пов'язані з динамічними та тембровими градаціями - від ледь чут ної звучності до бурхливих сплесків. Зазначено, що творчість І. Шамо посідає важливе з погляду методології місче в історії розвитку хорового мистецтва. Композитор створив оригінальний жанр хорової фролкопери, відкривши нові можливості для розвитку творчої діяльності.
Ключові слова: І. Шамо, хор, хорова творчість, фролк-опера, композитор.

The article highlights the features of Igor Chamo's choral works. The place of these works in the choral literature of Ukraine is emphasized. The main features inherent in the composer's choral work are identified. Composition method of Chamo is associated with the reproduction of folklore images that are embodied in the author's material. There is a bright melodic, intonation proximity to folk songs, great attention to the program beginning. The musical language of Chamo is quite melodic and expressive, and at the same time it develops according to modern compositional techniques. The composer's desire to present intonation layers that are tangent to archaic forms of folklore is noted. The choral compositions use melodies with the prevalence of the astute principle, the intonation turns of a small ambition, with the intervals of seconds and quarts. Often, the presence of jumps is offset by the downward or upward movement. The composer uses elements such as chants, whispers, exclamations, which likens them to folk music, and also corresponds to the leading tendencies of composer's creativity. The use of folk music accentuates the connection with folklore origins. Often there are chord constructions that result from linear thinking. There are such characteristic techniques of choral writing, such as juxtaposition of choral groups, combining of different performing groups, gradation of dynamic and expressive levels. The use of different choral groups makes it possible to obtain the smallest nuances associated with dynamic and timbre gradations - from the barely audible sound of violent bursts. It is noted that I. Chamo's creativity occupies an important methodological place in the history of choral art development. The composer created the original genre of choral folk opera, opening up new opportunities for the development of creative activity.

Key words: I. Chamo, choir, choral creativity, folk opera, composer.

Київського національного університету

культури і мистецтв

Постановка проблеми в загальному вигляді. В умовах переосмислення спадку українських композиторів, які працювали в радянські часи, надзвичайно важливо закцентувати увагу на їхній творчості. Їхня діяльність, результатом якої стали численні твори, має велике практичне значення, адже вона безпосередньо вплинула на становлення сучасної музичної академічної хорової практики. Ігор Шамо є видатним українським композитором, чиї вокальні опуси широковідомі. Проте його хорові твори, які посідають важливе місце в його творчому доробку, є малодослідженими. Відповідно, доцільним є виділення характерних рис хорового мислення Шамо та визначення їхнього місця в хоровій літературі України.

Аналіз останніх досліджень і публікацій. Риси хорового стилю Ігоря Шамо висвітлено в працях О. Батовської. Питання втілення програмності в фортепіанних циклах І. Шамо розкривається В праці В. Зінченко. Деякі риси хорових творів українських композиторів, написаних на слова І. Франка, досліджено в роботі Л. Нємцової. Риси хорової творчості українських композиторів-піснярів 50-70-х років XX століття висвітлено в праці Н. Перцової та В. Дорофєєєвої. Попри наявні розробки, чимало аспектів хорової творчості І. Шамо залишаються малодослідженими.

Виділення не вирішених раніше частин загальної проблеми. Хорова творчість І. Шамо не здобула достатнього наукового обґрунтування та $€$ такою, методологічне значення якої не досить висвітлене.

Метою статті $€$ аналіз особливостей хорового мистецтва Ігоря Шамо та визначення його методологічного значення для розвитку національної музичної культури, адже вивчення вітчизняної 
хорової літератури є невіддільним компонентом фрахової підготовки диригентів вищих закладів мистецького спрямування.

Виклад основного матеріалу. Ігор Шамо композитор, творчий спадок якого є чималим, який включає як інструментальні, так і вокальні твори. І. Шамо створив три симфронії, концерт для фрлейти з оркестром, концерт для фрортепіано з оркестром, концерт для баяна 3 оркестром, симсронічні поеми, струнні квартети, низку фортепіанних творів, як окремих, так і об'єднаних у цикли. Проте набагато вагомішим внеском $€$ його вокальноінструментальні твори, адже саме завдяки своєму мелодійному обдаруванню він набув не просто популярності, а й любові широкої слухацької аудиторії. Варто згадати хоча б його пісню «Києве мій», яка була і залишається символом української столиці. Його вокальні опуси представлені камерними творами - піснями, музикою до кінострічок, а також більш масштабними вокально-інструментальними, серед яких вирізняються кантата «Співає Україна» на вірші Д. Луценка (1961), кантата «Дума про три вітри» на вірші П. Тичини (1948), а також низка рукописів інших кантат та ораторій, присвячених радянській тематиці, чотири хори на вірші І. Франка (1958) та хорова опера «ятранські ігри» для квартету солістів і мішаного хору a capella на лібрето і вірші В. Юхимовича (1978).

Важливим етапом для становлення творчого методу Шамо стало навчання в післявоєнні роки в Київській консерваторії по класу композиції у Б.М. Лятошинського. Борис Миколайович був досить суворим викладачем, який, помітивши потенціал у студента, всебічно сприяв його розвитку, даючи багато навантаження. «Видатний митець, людина широкої творчої франтазії, незламної волі, Борис Миколайович Лятошинський як учитель прищепив Ігорю Шамо не лише вміння професіонально мислити в творчості. Шамо успадкував від учителя головне - глибоку громадянськість творчості, прагнення йти в ногу з часом, тонко відчувати провідні морально-психологічні проблеми свого народу. Звідси і великий інтерес до українського і слов'янського фрольклору» [4, с. 5].

Вже у ранній період творчості виокремлюються провідні риси композиторського стилю Шамо це яскравий ліричний характер, мелодизм, інтонаційна близькість до народних пісень, велика увага до програмного начала. Саме ці принципи є наявними у всіх жанрах, до яких звертався Шамо. Важливо зазначити, що ці ознаки можна віднайти у різних за жанровим спрямуванням творах ще й тому, що композитор одночасно працював і над музикою до кінострічок, і над піснями, і над хоровими опусами. Ця універсальність не лише підкреслює надзвичайну обдарованість композитора, а й виступає показником можливості певних паралелей, які могли стосуватися творів, написаних в один період часу. В. Зінченко, аналізуючи фрортепіанний цикл, наголошує на романтичних рисах у творчості Шамо, які зумовлюють великий інтерес до його музики з боку великої слухацької аудиторії. «Композитор трактує картинну програмність у романтичному ключі, що знаходить вираження у свідомому використанні ефектних колористично-фрактурних прийомів; водночас оригінальні звукозображальні, метроритмічні, фрактурні знахідки І. Шамо, органічне відтворення народного духу вказують на призначення музики для широкої демократичної аудиторії» [3, с. 147]. Багато в чому окреслені риси притаманні й іншим творам Шамо, написаним в інших жанрах.

Ігор Шамо володів надзвичайним даром, адже в момент написання твору він уже чітко усвідомлював кожний елемент музичної тканини. Для нього проблема полягала не в тому, як розвинути певну мелодію, а яку саме обрати, адже кожна 3 них була вже певним сталим комплексом виражальних засобів. «Я обираю одну мелодію із сотні інших мелодій, що звучать у мені. Найточнішу інтонацію 3 мільйона інших варіантів. А ще для мене твір (особливо це стосується пісні) народжується в комплексі: мелодія, гармонія, ритм, інструментовка. Немає ніякої приблизності й туману, загальних фрорм руху. Я бачу відразу кожну деталь, яка виконує свою фрункцію в народженні образу» [4, с. 6].

Варто зазначити, що хорову творчість Шамо можна представити як процес розвитку творчих принципів, вінцем яких стали «Ятранські ігри». Перед цим твором було написано низку циклів, зокрема хоровий цикл «Летять журавлі» на слова українських поетів (А. Новицького, Д. Луценка, В. Сосюри, Т. Одудька, П. Воронька), чотири хори на вірші І. Франка, «Карпатська сюїта», десять хорів на слова Лесі Українки, десять хорів на слова українських поетів. Прагнення до циклічності можна виділити як одну з базових для композитора. Його інтерес до поезії українських поетів сучасників і класиків - $є$ також виразною рисою стилю. Досить часто вони виступають своєрідною музичною даниною творчості літераторів.

Чотиричастинний цикл на слова І. Франка композитор написав до сторіччя від народження поета. Чотири частини циклу - це «Осінь», «Зима», «Весна», «Гримить» - були написані на поезії Франка, які входили до різних збірок. «Осінь» - на вірш «Осінній вітре» 3 циклу «Осінні думи», частина «Зима» - на основі поезії «Сипле, сипле, сипле сніг» із «другого жмутку» драми «Зів'яле листя, «Весна» - на поезію «Не забудь, не забудь» (сьомий номер циклу «Веснянки»), «Гримить»-на текст Франка «Гримить! Благодатна пора наступає!» (друга «Веснянка»). В цьому творі композитор втілює суто романтичний принцип - проєкції людських почуттів на світ природи. Подібні традиції формуються ще в XIX столітті та стають 
базисними для світогляду та творчих принципів тогочасних композиторів. «Загалом, І. Шамо створив колористичні хорові мініатюри, в яких уміло застосував тонкі градації динаміки, поєднав різні типи фрактури та вдало переніс фрормотворчі властивості поезії на музичну архітектоніку. Завдяки цим і іншим виразовим засобам цикл став одним із прикладів музичного відображення Франкових думок про співвіднесення природних явищ із психологічно-емоційними відчуттями людини» [5, с. 135]. Викликає захват надзвичайно тонка робота композитора 3 хоровою фрактурою. Використання хору дає можливість видобути найменші нюанси, пов'язані 3 динамічними та тембровими градаціями - від ледь чутної звучності, яка передає найпотаємніші почуття, до найбільш бурхливих її проявів.

У своєму хоровому творі, який є новаторським за жанром, а саме у фолк-опері «Ятранські ігри», Шамо намагається створити за допомогою хору картину народної обрядовості. $€$ певні розходження, пов'язані з тим, чи є прямі паралелі або цитати з народної музики у цьому творі. Хорова партитура володіє здатністю передати національний колорит, і «митець занурився у глибинні шари української народної творчості та відтворив у синтетичному, соковитому й барвистому музичнотеатральному дійстві магічну красу купальського обряду. Не використавши жодного автентичного фрольклорного зразка, він створив враження дійсно народного музикування» [4, с. 8]. Якщо в низці праць стверджується відсутність народнофрольклорних відповідників музичному матеріалу опери, то в інших роботах зазначається наявність однієї пісні, яка має фрольклорне походження, а саме - «Там, де Ятрань в'ється». «Досить цікавим $€$ те, що композиторська майстерність І. Шамо дала змогу створити хорову оперу, яка сприймалась як та, що має народні витоки, проте в усьому циклі використано лише одну фрольклорну пісню «Там, де Ятрань в'ється», тоді як інші номери є результатом авторської творчості. На генетичному рівні їхня ритмічна, гармонічна, ладова та формальна структури споріднюють їх із народними піснями» [6, с. 431]. Важливо зазначити, що весь музичний матеріал, а не лише один епізод, хорової фролк-опери створює враження перенесення в народне дійство. Відповідно, здатність передавати інтонаційність і ладову природу фрольклору виступає провідною ознакою композиторського стилю Ігоря Шамо.

Саме хорова фролк-опера Шамо надихнула на створення твору в цьому жанрі композитора наступного покоління - Євгена Станковича, який написав «Коли цвіте папороть» у 1978 році. Свою хорову оперу Шамо також завершив у 1978 році, проте писати почав ще в 60-х роках. Ідея твору прийшла композитору після фрольклорних роз- відок, які проводились у цій місцевості - Ятрані. «І. Шамо пощастило побачити справжній купальський обряд, який надовго залишився у його пам'яті. Краса мелодій, пластичність і магічна привабливість рухів танцюючих запалили уяву композитора. Саме 3 того моменту йому захотілось створити хоровий твір, придатний до сценічного втілення» [2]. Можна наголосити на тих рисах, що вирізняють цей твір та $€$ ознаками, що свідчать про прагнення відтворити дух і специфріку українського фрольклору. Насамперед, композитор намагається представити ті інтонаційні шари, які відповідають не сучасним, а архаїчним. Це досягається завдяки використанню в мелодіях остинантного принципу, інтонаційних зворотів невеликого амбітусу, з обіграванням інтервалів секунди, висхідної кварти. Наявність стрибків досить часто компенсується заповненням їх низхідним чи висхідним поступальним рухом. Надзвичайно майстерно композитором використовуються такі елементи, як скандування, шепіт, вигуки. 3 одного боку, це $€$ проявом саме народного музикування, з іншого відповідає провідним тенденціям західної музичної культури. Саме в музичному авангарді велика увага починаючи з початку XX століття надається більш експресивним способам звуковидобування, менш вокально оформленим, які акцентують увагу на сонориці звучання.

У ладовому аспекті в хорових творах Шамо використовуються елементи ладів народної музики. Вони часто підтримуються такими гармонічними акордовими побудовами, які дають чітке усвідомлення, що це твір другої половини XX століття. Начебто «випадкові» співзвуччя дають алюзію на естрадну музику, водночас вони $є$ результатом лінеарного поліфонічного мислення. Яскраві зіставлення хорових груп, прагнення урізноманітнити фрактуру твору створюють оригінальну партитуру. Поєднання вокальних і декламаційних епізодів фрормують драматургію твору. У різних номерах використовується інший склад хору - деякі епізоди виконуються лише жіночими голосами, лише чоловічими, усім складом хору, солістами, які підтримуються ледь чутним фооном хору.

Проаналізувавши вибрані хорові твори Шамо, можна наголосити, що вони постають результатом поєднання традиційного та новаторського начал. Зокрема, його музична мова, яка є досить мелодійною та виразною, вдало поєднується із сучасними прийомами. «Хорова спадщина І. Шамо вирізняється тяжінням до синтезування стилю і використання сучасних прийомів музичного висловлення» [1, с. 49].

Висновки. Хорова творчість Ігоря Шамо посідає важливе місце в хоровій літературі України. Композитор зміг створити унікальні музичні зразки, які стали надбанням не лише профресійної академічної сорери, але й отримали широку 
популярність серед публіки, орієнтованої на менш серйозні опуси. Шамо зміг синтезувати надбання попередньої композиторської школи та відкрити нові горизонти, пов'язані з поєднанням фрольклорних витоків, які творчо перевтілюються в авторському тематизмі композитора, із новітніми техніками. Традиції, закладені в хорових творах Ігоря Шамо, є одними з провідних у сучасній композиторській хоровій літературі, стаючи ознакою національної школи.

\section{БІБЛІОГРАФІЧНИЙ СПИСОК:}

1. Батовська О. Риси хорового стилю Ігоря Шамо (на матеріалі циклу «Летять журавлі»). Вісник Львівського університету. Серія : Мистецтво. 2015. Вип. 16. Ч. 2. С. $48-56$.

2. Батовська О. Художньо-стильові орієнтири опери «Ятранські ігри» Ігоря Шамо. URL: http://www.yatran.com.ua/articles/660.html (дата звернення: 24.10.2019).
3. Зінченко В. І. Шамо. Фортепіанна сюїта «Картини російських живописців» (до питання втілення програмності в фрортепіанних циклах українських композиторів другої половини XX століття). Вісник ХДАДМ. 2011. № 8. С. 145-147.

4. Лірично-сонячне світло в музиці. Інформаційний бібліографрічний список для організаторів дитячого читання до 90-річчя від дня народження визначного українського композитора Ігоря Шамо / упоряд. В. Олійник. Київ : НБУ для дітей, 2014. 28 с.

5. Нємцова Л. Хорова Франкіана: соціокультурний та жанрово-стильовий виміри : дис. ... канд. мистецтвознавства : 17.00.03 / Державний вищий навчальний заклад «Прикарпатський національний університет імені Василя Стефаника». Івано-Франківськ, 2017. 277 с.

6. Перцова Н., Дорофрєєва В. Риси хорової творчості українських композиторів-піснярів 50-70-х років XX століття. Мистецтвознавчі записки. 2018. Вип. 33. С. 428-434. 